\title{
Breeding Futures: Masculinity and the Ethics of CUMmunion in Treasure Island Media's Viral Loads*
}

\begin{abstract}
In a recent interview, pornographer Paul Morris claimed his studio, Treasure Island Media (TIM), is a 'laboratory exploring the vital sexual symbiosis of human and viral DNA.' Departing from that claim, I examine his porn text Viral Loads to explore its implications for thinking future-orientated masculinities and community formations. I claim that Viral Loads forces us to rethink modern ideals of individual autonomy and bodily integrity and alludes to alternative community formations enacted not by holding something in common but by relentlessly giving and exchanging foreign matter. By depicting 'loads' circulating between bodies posited as interfaces, Viral Loads gives us a porous and impure form of masculinity. In so doing, it breeds a queer future in which community ethics becomes an ethics of cummunion, a cummoning with strangers that is offered as an alternative to the politics of self and other.
\end{abstract}

Keywords: bareback; masculinity; HIV; immunity; community; posthumanism

\section{Introduction: chasing symbiosis}

Since its creation in San Francisco in the late 1990s, Treasure Island Media, also known by the acronym TIM, has become not only one of the most controversial gay porn studios operating in the so-called 'post-AIDS' world, but also one that has received a lot of scholarly attention. ${ }^{1}$ TIM's popularity is certainly due to the particular way in which it embraces 'bareback' - that is, condomless — sex, presenting the exchange and accumulation of bodily fluids, as well as their potential risk, as the targets of libidinal investment. $^{2}$

\footnotetext{
* The Version of Record of this manuscript has been published and is available in Porn Studies
} (2018). http://www.tandfonline.com/10.1080/23268743.2018.1469317 
The infamous popularity of such scenes is, however, not only a consequence of what we see men getting up to. It is also the result of how articulate Paul Morris, the founder of the company and one of its pornographers, has been every time he has spoken publicly about TIM's work. For instance, in his speech entitled 'No Limits: Necessary Danger in Male Porn,' delivered at the World Pornography Conference in Los Angeles in 1998, Morris defended his work by positioning it as documentary filmmaking, as a trustworthy record of contemporary gay male sexual practices. Distancing himself from the work of mainstream gay porn studios like Falcon or Titan and what he regards as the 'very little truth-content' of their 'slick porn,' Morris claimed for himself the role of ethnographic filmmaker documenting the "mess of viruses, germs, test-results, imperfections and real intimacy' that he associates with the reality of a queer male subculture defining itself heroically against homonormativity (Morris 2011). To him, by embracing risk and rejecting the assimilationist rhetoric of mainstream LGBT politics, gay men become the new heirs of queer counterculture. Still, TIM's status as documentary filmmaking is not as straightforward as Morris has claimed. As porn and media scholars like Linda Williams (2014), Feona Attwood (2002), Laura Kipnis (1999) or Susanna Paasonen (2011) have argued, porn is less about documenting reality and more about producing a reality-effect thanks to what Paasonen describes as 'a complex interplay between authenticity and artifice' (17). Porn is 'authentic' because, after all, it is a record of sexual acts that have indeed taken place. But it is also artificial inasmuch as each scene is performed and often especially lit for the camera, with performers and cameramen positioned in such as a way as to grant the viewer maximum visibility and a mediated sense of physical closeness to the action. Such a view is also shared by Tim Dean who, despite accepting TIM's porn as an ethnographic record, nonetheless still acknowledges the ways in which its documentary 
aesthetics depends on a series of particular pornographic techniques that '[betray] the impotence of vision alone to capture raw sex' $(2009,134)$. Techniques such as subtitling, compromise money shot (when the top pulls the penis out in order to make the ejaculation visible), reverse money shot (when the bottom pushes out the semen in his rectum), unedited ambient sounds, cameramen intentionally visible in the shot, and even the occasional presence of the director's voice speaking off-camera as the action unfolds, are all stylistic decisions used to produce and reinforce the effect of documentary realism pursued by TIM (131-144).

However, what strikes me in Morris's speech, delivered two years after antiretroviral therapy and viral load tests were introduced to successfully manage HIV infection, is that it shows an understanding of contemporary gay male subjectivities and sexual practices, as well as their politics, being enacted at the intersections of the body with clinical discourses, medical research, biopolitical technologies, and microscopic forms of quasi-life. More recently, in an interview with Paasonen, he expanded on that point and on TIM's role in relation to it:

TIM is two things, basically. We're a developing and living archive of real male sexual experience. And we're a laboratory that performs experiments that the men involved in our community propose. You could say that we're a genetic laboratory exploring the vital sexual symbiosis of human and viral DNA. For the most part, gay porn pretends to represent experience without peril, experimentation without damage. Most gay porn hides behind a facade of 'safeness.' But in my case, the men in my work are considered and prized for being damaged, for having taken what conservative gays deem 'the ultimate risk' and lost. In a world increasingly dominated by the medical gaze, to willingly live in symbiosis with a virus is seen as irrational and socially expensive. I see it as necessary and revolutionary. (Morris and Paasonen 2014, 217-18)

Here, Morris claims TIM's bareback porn to be more than an ethnographic record of the sexual practices of $21^{\text {st }}$-century gay men. To him, TIM should also be seen as a creative, 
future-orientated, and necessary research enterprise invested in the production of new chimeric bodies. Posited as a contemporary form of symbiogenesis, bareback sex becomes TIM's research method and, framed in such way, offers itself for ontological speculation.

Sure, it is likely that Morris's statements are a crucial part of the very successful marketing strategy of his studio, one through which it sells dreams of a transgressive sexual utopia at least as much as it sells pornography. Still, his idea that HIV seroconversion might lead to new forms of human-viral symbiogenesis is not so farfetched. As studies in immunology have shown, the incorporation of retroviral genes into human DNA is an observable phenomenon in human-retrovirus co-evolution. For instance, in an article published in the Journal of the Royal Society of Medicine, Frank Ryan notes how, as early as the 1970 s, scientists had already identified retroviral genetic material built into the genome of mammals, including humans (Ryan 2004).

Thanks to a long process of co-evolution that involved the incorporation of their genetic material into the germ cell lines of their hosts, some retroviruses developed a survival strategy based on vertical, rather than horizontal, transmission. In other words, the genes responsible for coding the synthesis of viral proteins became part of the human genome and started being passed down by progenitors as part of their offspring's own DNA, thus no longer requiring the exposure and infection of new hosts in order to secure replication and survival. Added to that, and 'assuming that the exogenous forebears of our human endogenous retroviruses once behaved as highly contagious infections, following transmission pathways akin to that of $\mathrm{HIV}-1$ ' millions of years ago (Ryan 2004, 560), it is not hard to imagine a possible distant future when HIV itself could become written into the human genome, in what could be seen as yet another instance of symbiogenesis in a mutualist process of human-viral co-evolution. 
Such a possibility also makes sense in light of recent studies on acquired immunity which argue that, in order to be successful, pathogens need to balance their virulence with their infectivity. What that means is that a pathogen cannot be so virulent that it ends up killing its host before the latter gets a chance to transmit it. Thus, instead of pathogens and hosts evolving separately — the former to kill faster and the latter to become more efficient at defending itself against a foreign agent—both the pathogens and the immune systems of their host species co-evolve. That process has more to do with an increase in their levels of tolerance to one another than with an escalation of a war-like, zero-sum game aimed at the victory of one side and the defeat of the other (Hedrick 2004).

What these recent developments demonstrate is that the paradigms that sustain immunology have come a long way since immunity was first discovered. As authors such as Ed Cohen (2009) or Roberto Esposito (2011) have argued, the modern body had been understood as a private territory with borders in constant need of defence against foreign invasion. From the mid-1600s onwards, with the transposition of paradigms of immunity-as-defence from political theory to medicine, and their subsequent strengthening thanks to Élie Metchnikoff's foundational immunological research of the late 1800s (Metchnikoff 1905), modern thought started conceiving the body as a discreet territory defined through the enforcement of its borders with the outside environment. In Cohen's words, ‘the modern body aspires to localize human beings within an epidermal frontier that distinguishes the person from the world for the duration which we call a life' (7). Thanks to the work of Metchnikoff and others, immunity came to be seen as a mechanism whereby a body establishes its biological self — its identity — and protects its integrity through a process of self/non-self discrimination. This 'modernisation' of the body through the paradigm of immunity 
also operated in tandem with wider biopolitical institutions and discourses that were developed to govern life, to preside over the production of the subject, and to manage the truth of the self in its difference from the other-what Michel Foucault named 'subjectivisation' (1978, 1983, 1990, 2003, 2005).

However, thanks to developments in contemporary immunology, the self/nonself discrimination that played such an important role in modern understandings of immunity has come undone as a result of what Alfred Tauber calls the "'ecological sensibility" of contemporary biology' (2000, 244). Accordingly, the body is no longer conceived as a discrete closed unit but as an ecosystem, and immunity thus becomes less a defence against foreign matter and more a process of interfacing in which foreign matter can be tolerated in the interest of the organism, its survival and, crucially, its evolution (Tauber 2017, 164). As a consequence, biological bodies have, not only been reconceived as 'heterogeneous, partially comprising exogenous entities,' but are also now seen to exist in a co-constitutive relationship with their surroundings whereby 'the organism is constructed by its environment, as well as it in turn constructs it' (Pradeau 2012, 269).

Despite all that, Paul Morris's 'vital symbiosis of human and viral DNA' will, at best, only take place in a very distant future. At worst, it is nothing but braggadocio by a pornographer who has built a career and subcultural celebrity status out of the controversy of his pornographic texts and public statements. Still, if we approach bareback — simultaneously a porn subgenre and a de facto gay male sexual practice — in terms of what Paul Preciado (2013) calls the 'pharmacopornographic regime,' we cannot so easily discount Morris's words.

By 'pharmacopornographic,' Preciado means 'the processes of a biomolecular (pharmaco) and semiotic-technical (pornographic) government of sexual subjectivity' 
that define contemporary biopolitics $(2013,33)$. Preciado argues that contemporary subjectivities are produced and maintained thanks to a system of chemical, semiotic, and technological prostheses that attach to bodies, in-forming them as they do so, giving them both their form and their meaning. Building on Teresa de Lauretis notion of 'technology of gender' (1987, 1-30), Preciado argues that 'the pharmacopornographic regime functions like a machine of somatic representation in which text, image, and the corporeal spread through the interior of an expansive cybernetic circuit' $(2013,180)$ and are responsible for creating 'toxic-pornographic subjectivities' $(2008,108)$.

Those linguistic, imaginary and material plug-ins operate as catalysts in processes of subjectivisation, intervening within and feeding back into the body conceived as an interface. In that context, as one of a myriad of prostheses in-forming contemporary subjectivities through their mediation of desires and pleasures, pornographic texts code meanings and value systems and in-corporate them in the bodies of particular sexual-linguistic communities. Thus, as a form of 'sexual vernacular' that 'makes no sharp distinction between "sex" and "text"' (Patton 1991, $44,45)$, pornography is an important resource to understand how contemporary subjectivities are coded. Such an avenue of enquiry, however, must not only take into account what happens on screen but it must also consider the statements and institutions that environ and frame its sexual scenes. It is in that context that, departing from Morris's discussion of TIM's work, I will now focus on the intertextuality of his production Viral Loads, in order to examine the ways in which it codes both masculinities and sexual communities. The reasons for focusing on this particular pornographic text shall become clearer as the argument progresses.

\section{Viral Loads}

Released in 2014, Viral Loads gathered media attention for its eroticisation of HIV 
transmission. ${ }^{4}$ Its title refers both to the technical term used to name the number of viral particles in a millilitre of HIV-positive blood, and to the usage of the word 'load' among barebackers as another name for ejaculate. Viral Loads thus not only promises to show us men sharing their loads with one another, but it also wants us to know-or at least to believe - that such loads are viral, that alongside semen they also carry HIV. The film opens to the sound of a storm and a rotating world globe with the words 'TIM GLOBAL' written on it, followed by TIM's pirate-like logo of a blackand-white skull above two crossed swords. Once the sound changes to a meditative electronic drone, a variation on TIM's logo appears on screen. Here, the skull is metamorphosed into the head of a jester through the addition of a four-pointed hat reminiscent of the motley attire of Medieval and Renaissance court entertainers. The insignia is completed by the Latin words 'IOCARE SERIO ET STUDIOSISSIME LUDERE' written in a thick serif typeface around the jester skull. The whole thing conveys the overall impression of being a powerful sigil, one that suddenly comes alive when the skull's eyes light up in bright red.

Before discussing its scenes, it is worth reflecting on the unique presence of this symbol both at the start of Viral Loads and on the front cover of its DVD release. It sets Viral Loads apart from all other TIM productions, as the latter only use the regular TIM logo and, unless they're thematic compilations of existing scenes, always have production shots on their front covers. The Viral Loads insignia and its usage as the single image on the DVD front cover, thus frame this particular porn text as a stand-out item in TIM's catalogue.

'Iocare serio et studiosissime ludere' ('to jest in seriousness and to play in the greatest earnest') is a phrase associated with Marsilio Ficino's 1496 commentary on 
Plato's Parmenides. Appearing at the start of Ficino's preface to the work, the phrase concludes its opening sentence as follows:

It was the custom of Pythagoras, Socrates and Plato to conceal divine mysteries everywhere beneath figures and veils, to modestly dissimulate their wisdom, in contrast to the sophists' arrogance, to jest in seriousness and to [play] in the greatest earnest.

(Ficino 2012, 33)

Discussed by Renaissance scholars, this passage has been read as an example of how, for Ficino, philosophical wit had been used by Socrates to conceal and protect the higher truths of ancient theology from those who were considered undeserving of them (Knox 1989, 121-123). Ficino's aim was to highlight a certain "'gladness" (laetitia) of spirit that was [in his view] the proper prerequisite for serious philosophising; a refined but hedonistic vitality that would naturally lead to a quickness and profundity of thought' (Allen 1986, 438). Further, this approach to philosophical method was part of a wider Renaissance interest in the wisdom of fools and in the connection the latter were seen to establish between the basest and the most admirable, between body and soul, appearance and reality, the grotesque and the beautiful. Or, as John Lepage puts it, 'the unspeakable folly of human existence, the madness that in order to glimpse the truth we must indulge in fictions or follow the imagination wherever it takes us' $(2012,79)$.

Morris's allusion both to Ficino's Neoplatonism and to the figure of the jester at the start of Viral Loads complicates the pornographer's earlier views on the documentary nature of his work. By hinting at Viral Loads as an exercise in philosophical wit, Morris seems to wilfully take up a new role, that of the wise fool. No longer embracing pornographic texts simply as a truthful record of reality, he hints at figures of rhetoric known for dissimulating truths with appearances, perhaps telling us that, underneath the cover of his pornographic fantasy, he is offering something else, a different grasp on reality. Through the intertextuality of the insignia with which he 
decided to open Viral Loads, he invites us to look beneath the veil of pornography and its depiction of sex, to seek what kinds of thinking may be hiding there. Not only that, but in requiring us to decipher that symbol, the pornographer-as-jester appears to be asking us to prove how deserving we are of the hidden knowledge he will have buried in his work. As he puts it in his interview with Vice following the release of the film: The point of Viral Loads was for those people to whom it would make sense to look at it, say it, own it, and fucking move on. Fucking move on! In 20 years, there will be references to HIV, and young gay men will astonish and horrify people who are now in their 20s when they say, 'What the fuck are you talking about?' (McCasker 2014)

With this statement, Morris hints at the double status of Viral Loads as both a pornographic text and some sort of manifesto for a 'post-AIDS' future. For him, eroticising HIV and fantasising about its transmission appears to be a means to foreground the structures that discipline our bodies and our pleasures. While doing so, he invites us to liberate and transform ourselves by staying true to what we desire: ' $\mathrm{He}$ who makes a beast of himself removes the pain of being human,' claims the epigraph attributed to Samuel Johnson that appears on screen right after the jester symbol. ${ }^{6}$

Morris's allusion to figures of rhetoric, the way in which he discussed Viral Loads, and his uncharacteristic use of an epigraph at the start of the text, they all complicate its reading. They add to the known difficulties in clearly defining pornography as a genre whether through its content, its aesthetics, its politics or what may be seen as its primary use, sexual gratification (Rea 2001; Maes 2013; Attwood 2018, 82-111). Further adding to its intertextual complexity, Morris's promotional text for Viral Loads is rather opaque:

Mansex is a virus, one that uses men as its host. Some try to resist it. Others embrace it as the source of life and meaning. We live to breed the sex-virus, to pass it on to every random anonymous dude we meet and fuck. It's how we reproduce, man. 
We shoot viral loads every time. Our jizz ain't for making babies. Our sex spreads like wildfire, squirting out of one man's dick, shooting deep inside another, then another and another.

Join in, buddy. You'll never look back. ${ }^{7}$

What is being said here? If, as its title implies, Viral Loads is about the eroticisation of HIV transmission, why does Morris not name the actual virus? Instead, by equating 'mansex' with 'virus,' by using the compound noun 'sex-virus,' he allows multiple ways of decoding the text, including the one whereby it is not HIV but (masculine) sex itself that 'spreads like wildfire' and reproduces without babies. Interestingly, if we take up that reading, Morris's wise fool rhetoric starts unfolding in sharp contrast to the antisocial positions that have gained momentum in queer scholarship in the past decade.

Calling for an embrace of negativity and the death drive, queer scholars like Lee Edelman have rejected politics on the grounds that all political projects, being futureorientated, necessarily inhabit heteronormative forms of temporality. They require heterosexual reproduction and depend on the figure of the Child to whom the future is seen to belong (Edelman 2004). Against such antisocial or anti-relational stances, Morris's quote above alludes to an alternative way in which the future may still be thought through queer forms of relationality. In what I read as a rejection of Edelman's reduction of queerness to the death drive, Morris calls for the creation of new futureorientated forms of queer communion, fuelled by 'mansex' spreading 'like wildfire' and 'jizz' that isn't used for 'making babies.' Here, just like in his interview with Paasonen, Morris appears to be claiming that his is a business that takes up a hedonistic present in order to fashion new queer communal futures.

With that in mind, I would now like to turn to the actual scenes that make up the pornographic text. Viral Loads is comprised of nine different scenes presented as chapters, each numbered and introduced by its title on screen, followed by two bonus 
sequences. Through the numbering of each chapter, Viral Loads is given some degree of formal unity. That unity is strengthened by the fact that scenes one, two and three, as well as the first bonus sequence, construct a singular narrative centred on Blue Bailey, whom the press pack describe as an 'uber-whore.' It is on that narrative that I'd like to focus, given its importance to the overall cohesion of the text.

Scene one, 'Adult Bookstore Basement Fuck,' is a one-to-one sexual encounter in which Bailey is fucked raw and rough by Steven Richards, whom Bailey addresses as 'sir.' It is structured around a progression from oral sex to anal and back to oral, with the camera moving mostly between close-ups of penetration and close-ups of Bailey's face as he moans and grunts. The seeming roughness of the scene becomes complicated when Richards asks Bailey 'You all good? Yeah? Is that okay?'-a series of questions that are also subtitled, hinting at the care that underlies the fantasy of submission. Eventually, the top ejaculates with a compromise money shot, but the scene does not end there. Instead, its temporality is expanded with Richards continuing to fuck Bailey until the latter also ejaculates while rimming the former. Richards then collects Bailey's cum with his hand and feeds it to him. The scene culminates with Richards, the top, calling Bailey, the bottom, a 'good boy,' and a passionate kiss sharing Bailey's cum.

The following scene, 'Blue's Gloryhole Dessert,' is preceded by the text '20 minutes later... Before leaving the bookstore, Blue needed the taste of more cock.' As the title suggests, this is a scene of oral sex at a gloryhole, one in which the camera maintains a continuous close-up of Bailey's face as he sucks an anonymous man to completion only to then lick the drops of cum that fall on the floor. Despite the close-up shot, the reverberation of the ambient sounds helps to spatialise the scene in a much wider room where other men are heard moaning and coughing in the distance. 
Both scenes one and two lead up to a third scene, 'Blue's Man-worship Gangbang,' described in the promotional text as having come about when, the day following the shoot in the adult bookstore, Bailey approached Morris saying 'he wanted some kind of man-worship initiation.' The resulting scene is one in which Bailey is fucked bareback by a large number of men. However, while the previous two scenes progressed in a linear narrative fashion, scene three starts with its ending. It opens with a close-up of a pighole inserted in Bailey's rectum and another man's hand with most of his fingers inside it. ${ }^{8}$ The close-up cross-dissolves to a bedroom, where Bailey is in bed, on his fours, sucking one man and surrounded by several others. The camera cuts to one of the other men walking towards the foreground with a jar full of a white, creamy content, which he extracts with a large pipette and inserts into Bailey's rectum through the opening of the pighole. 'Fuck yeah, fill it up... keep going... drink it up' can be heard uttered in the background under an echoing sound effect.

After the above sequence, a jump cut is applied and signalled by the text 'one hour earlier.' Starting with a slow-motion scene set to electronic music in which Bailey is seen kissing one man, we learn that the scene actually kicked off with Bailey being gang-fucked while various men kissed and masturbated each other in the background, waiting for their turn with him. As an increasing number of men fuck and ejaculate inside him, cum is seen dripping out of Bailey's anus, only to be licked and eaten by Max X, a model whose only role seems to be making sure no cum is wasted. There is a strong sense of relentless giving and exchanging here. The relentlessness is heightened by the apparent consecutive 'loads' that some men are seen depositing inside Bailey, often captioned by subtitles like 'Tom's second load' or 'Logan's third load,' and by the almost immediate transfer of the loads out of Bailey's rectum and into Max X's mouth. 
The scene eventually leads to the closing jar sequence that we have already witnessed. In this iteration, however, the words 'poz cum' can be read on the lid of the jar before its contents are injected into Bailey's rectum, a clear attempt at circumventing the invisibility of HIV itself, as Dean noted in his discussion of bareback porn (2009, 112-13). This second appearance of the jar sequence is also accompanied by a slowingdown of the footage and the introduction of an electronic drone sound. The scene closes with Bailey and Max X kissing cum off each other's mouth followed by a head shot of Bailey smiling as laughter is heard echoing in the background.

Interestingly, it is not until the bonus features that the whole narrative becomes complete and, again, by making use of yet another jump cut. It is only then, after six other, unrelated, scenes that we are eventually shown cum being collected to fill the jar introduced in scene three. Making use of an uncharacteristic $3 \times 3$ split screen, we see nine men sat on chairs, filmed only from their necks down, masturbating into the jar, adding their contribution to what, according to the press pack, were '200 poz loads.' Just like the words 'poz cum' were deployed to overcome the invisibility of HIV, anonymity functions here in much the same way, to strengthen the affective charge of the fantasy. By not showing the faces of the men in this last sequence Morris intensifies the aesthetics of transgression pursued with Viral Loads. Considering that the vast majority of TIM models are clearly recognisable by their faces and listed on its online roster, Morris's decision to play with anonymity in this instance further contributes to the reality-effect of the porn text. Particularly so given that the scene was filmed in a legal context that still allows prosecutions for conscious exposure to- or transmission of-HIV (Lazzarini et al 2013; Ashford 2015). Invisibility and anonymity, as absences denoting presence, strengthen the reality-effect of HIV infection in Viral Loads. 
Considering that none of the actual sex scenes depicted are fundamentally different from most other scenes in TIM's catalogue, the controversy surrounding Viral Loads is not just the result of the sex we see but, rather, of its style and the sophisticated way in which Morris, the witty jester, makes use of intertextuality to play with presence and absence, visibility and invisibility. By doing so, he alludes to what Linda Williams describes as the "perpetual push and pull between on/scenity and obscenity as a part of the neoliberal dilemma of an ever expanding market for all sorts of sexual representations' (Williams 2014, 38). It is those stylistic decisions that, to me, set Viral Loads apart as a pornographic text. Rather than simply sticking to the conventions of style that have become TIM's signature, Morris's play with temporality through nonlinear editing, his use of explicit audio effects, entrancing drone sounds, chapter-like scenes and even a split-screen, all add to the aforementioned jester symbol and cryptic epigraph to tell us that what we see in Viral Loads is likely to be not what Viral Loads is really about.

Its truth-effect becomes further disrupted by the realisation that Blue Bailey was already living with HIV and with an undetectable viral load at the time the 'poz cum' scene was shot (Clark-Flory 2014). Concealment, this time of the model's serostatus, is used again to benefit the fantasy, or, as Bailey himself put it, to 'hype [the film] up' (Clark-Flory 2014). Even if that were not the case, medical evidence suggests that the virus itself can only survive outside the human body in very specific conditions, that 'HIV transmission has not been reported as a consequence of contact with spillages of blood, semen, or other body fluids' (Aidsmap).

To my mind, what Viral Loads offers beneath its play of artifice and reality is thus a rich text through which to think the ways in which 'post-AIDS' gay masculinities complicate modern understandings of the body and of the autonomous subject. My 
position here resonates both with Morris's manifested interest in human-viral symbiosis already discussed above, and with Gregory Tomso's view that barebacking supplements masculine subjectivity through the accumulation of foreign matter in the body $(2008$, 274). Viral Loads uses pornographic and narrative devices both to reassert masculinity as ideal and to transform it. On the one hand, through heroically enduring relentless 'breeding,' Bailey reiterates the norm of athletic masculinity. On the other, and as Byron Lee notes in relation to the masculinity of bareback bottoms, by reframing masculine athleticism as relentless bottoming, 'what was once an act of effeminacy is now a masculine act' (Lee 2014, 110). Viral Loads reproduces masculine ideals while nonetheless queering them through both the penetrability of Bailey's body and its radical porosity to foreign matter-its impurity.

This performance of masculinity, simultaneously athletic and impure, gains a particular relevance in the context of the biopolitics of Highly-Active Antiretroviral Therapy (HAART), administered as either Treatment-as-Prevention (TasP) or Pre- and Post-Exposure Prophylaxis (PrEP and PEP). After all, as Blue Bailey noted, most HIVpositive TIM models live with undetectable viral loads thanks to successful HAART regimes (Clark-Flory 2014). Notwithstanding the fantasy of HIV transmission depicted in Viral Loads, the reality is that, thanks to HAART, the bodies we see exchanging semen with one another are likely to exist outside the positive/negative binary upon which the seroconversion it eroticises would depend. Constituted as an 'elusive third term' between positivity and negativity, undetectability 'at once [increases] the capacity of a body and [subjects] it to a relentless regime of control' (Lee 2013). In other words, while undetectability allows a queering of Bailey's masculinity through a relentless embrace of penetrability and porosity to foreign matter, the biopolitics of antiretroviral 
drugs reinscribes Bailey's subjectivity within the masculine norm as a heroic form of life, at once allowing it exposure to risk and chemically shielding it from it.

It is in the context of such posthuman becoming - one in which the affordances of flesh, desire, and pleasures are at once increased by foreign matter and semiotic chains, and recaptured by biopolitical economies - that Viral Loads can be read as a kind of jester's wit, a pornographic fantasy that alludes to important changes in how gay male subjectivities are embodied. Thanks to the technoscientific developments that have been taking place since the late 1990s, the masculinity performed in Viral Loads cannot be fully captured by earlier understandings of bodies as enclosed spaces. Instead it is enacted by opening bodies to a seemingly endless number of 'loads.' At the same time, however, those bodies remain protected as standing reserves of life by being chemically reconditioned with HAART.

Emerging at the biopolitical intersection of semiotic, chemical, and corporeal feedback loops, I see Bailey’s masculinity as a ‘toxic-pornographic subjectivity’ (Preciado 2008; 2013). Both his body and subjectivity emerge as liminal interfaces where strict distinctions between self and other collapse in a relentless circulation of images, meaning and matter. Viral Loads then poses some important questions concerning the relationship between subjectivity and community, the one and the many. As Kane Race (2009) notes, HAART reiterates the sovereignty of the neoliberal subject through self-administration. By self-administering antiretrovirals, gay men also actively administer themselves in what constitutes a devolution of biopolitical control from medical institutions to the self-monitoring individual and his 'personal acts of consumption and compliance' (Race 2009, 115). Part of the wider privatisation of experience that characterises the neoliberal politics of self-care, HAART moved HIV away from the public sphere where the politics of the AIDS crisis had unfolded and into 
the private bodies of individuals, where life is regulated by self-administered chemical prostheses. As a consequence, according to Race, community nostalgia developed among people who had been affected by AIDS, a 'certain sentimental hankering [...] for the days of the crisis, when politics were authentic and community pure' (118).

However, as both Race (2009) and Preciado (2013) also argue, the emergence of a new, privatised and self-managed, biochemical theatre of biopolitical operations did not mark the end of queer communities and queer modes of futuring. What it did, instead, was to create the conditions for queerness and community to be differently thought and projected into the future through new forms of what Race describes as 'experimental and material engagements with the circumstances of life' $(2009,31)$. Or, what Preciado calls a 'copyleft gender politics,' the 'pirating of hormones, texts, body techniques, knowledge practices, codes, pleasures, fluxes, chemical substances, cartographies...' (389). That is, an appropriation of the new prostheses and tools of biopolitics for a 'contrasexual' becoming of the body away from its neoliberal status as a unit of life and labour and towards new modes of relating and forms of pleasure (Preciado 2000) —in short, new enactments of community.

\section{CUMmunion}

In Unlimited Intimacy, Dean claims that barebacking is worthy of scholarly attention as a subcultural practice due to the ways in which, as a form of transgressive biosociality, it catalyses new structures of kinship and non-normative queer identification through the sharing of HIV (2009, 92-96). As we've seen, however, HAART complicated that narrative of biosociality and kinship. So much so that, in a more recent article, Dean has had to readjust his earlier view of barebacking to what he sees as the 'mediated intimacies' of sex recaptured by the pharmacological apparatus of contemporary biopolitics (Dean 2015). Still, the biopolitics of biochemical self-management is also 
what allows for the 'pharmaceutically mediated utopia' that is Viral Loads (241), making the pornographic text a productive source to rethink not only gay male subjectivities but also community formations in the time of HAART.

Understanding community in terms of attributes that are recognised as shared by the members of a group is a long-established position in the social sciences. Traced back to the likes of Victor Turner, that position sees community being triggered by a recognition of the attributes the membership holds in common and that, therefore, allow members to overcome their individual differences (Turner 1995). The problem when it comes to forms of community predicated on the sharing of HIV is that the HAART regimes that make fantasies like Viral Loads possible also prevent the fantasy of HIV transmission to become an actual reality. HAART makes positive bodies uninfectious and negative bodies uninfectable; it operates as a chemical barrier to the sharing of HIV.

Nonetheless, as the reading of Viral Loads undertaken above highlights, there is still a strong sense of intimacy, complicity and care among the performers. The ways in which tops ask bottoms whether they're enjoying it; how tops are depicted as making Blue Bailey's wishes a reality; the giggles, the smiles, the laughter, and the passionate kissing, they all hint at the fact that, despite the ways in which HAART may function as part of the wider neoliberal atomisation of the social, that it still creates conditions of possibility for new forms of sociality and community to emerge. However, in order to understand how that may be happening, we must reconceptualise community away from relationships of recognition predicated on identifiable attributes shared by a membership.

In his study of community, Roberto Esposito (2010) traces the etymology of communitas back to munus, a Latin word positioned between 'duty' and 'gift.' Rather than emerging out of a sharing economy, Esposito claims that communitas is in fact 
about gifting unconditionally_about, he writes, "a "pledge" or a "tribute" that one pays in an obligatory form' (7). His line of thinking resonates with Massimo De Angelis's recent work on the nature of the commons, in which the political theorist argues that the commons must not be understood as goods or resources held in common. Instead, they must be regarded as a dynamic system of social relations - a commoning or a 'doing in common' that carries existing and new social relations into a collective future (De Angelis 2017, 119).

To go back to Viral Loads, I would like to argue that, in the context of HAART, the communities enacted on screen are similarly not predicated on something concrete being held in common by the men we see fucking and being fucked. They are instead enacted in the relentless giving and receiving of foreign matter, made possible through the radical openness and porosity of their bodies_-Viral Loads shows us 'breeding' as cummoning. What such perspective allows is a better grasp of Blue Bailey's incessant pursuit of 'load' after 'load,' only to then pass them away into the mouths of others. In Viral Loads, no 'load' is held in place and as such, no 'load' is held in common. Instead, what we see is a community cumming together, even if for only a few hours, through relentless acts of giving and exchanging, through an incessant eroticisation and actualisation of the porous potential of the body to that which could be seen not to belong there, to inflows of foreign matter.

\section{Toxic becomings}

Rather than having their subjectivity dependent on a clear separation of self and other, the bodies we see depicted in Viral Loads suggest themselves as perverse realitiesthey are porous, penetrable, multiple, and self-constituted in their openness to strangers. In operating their boundaries not as closed borders but as interfaces, they veer away from modern understandings of the (hu)man as a discreet self-enclosed unit. That is, 
even if the bodies we see in Viral Loads are made possible thanks to HAART, even if the biopolitics of the latter still produce self-administered subjects as sovereign, that sovereignty also creates the conditions of possibility for bodies to fashion themselves differently within the current biopolitical regime as radically impure queer multitudes.

Organised around a coming together that is also a cumming inside, the barebacking cummunities depicted in Viral Loads operate a displacement of the self. In them, the self becomes multiple. In so doing, their libidinal excesses push bodies towards an inhuman mode of relatedness. While they certainly embrace and stress some aspects of normative masculinity, they no longer posit masculinity itself as either impermeable or immutable. Instead, the masculine embodiments we see enacted in Viral Loads are toxic — not necessarily 'toxic' in the sense of oppressive to others, but toxic in and for their selves. That is, through opening themselves to what is foreign, both their masculinity and their humanity become self-polluting. They themselves become 'matter out of place,' to use Mary Douglas's famous definition of dirt (2002, 36).

In that context, their community ethics is no longer dependent on what bodies may have in common with one another. Instead, community becomes a pledge one makes to others on the condition that they will remain foreign and strange, not in spite of it. As such, Viral Loads advances a masculinity that is always-already queer, polluted and impure. At the same time, through the relentless flows of semen, foreign DNA, and antiretroviral drugs it depends on, the pornographic text presents us a view of contemporary embodied subjectivities as compromises in living-together. It not only functions as a critique of the modern autonomous subject and his bodily integrity, but it also constitutes a serious invitation for us to think the queer futures of our bodies, coded through an interfacing of visual, semiotic, libidinal, and biochemical prosthetic flows. 


\section{Notes}

1. 'Post-AIDS world' is a problematic term given how it can lead us to overlook the obscenely unequal levels of access to HIV care among different regions of the planet, ethnicities, and socio-economic strata. With that proviso in mind, the term is used here to refer to the placesgeographical, cultural, and social—where, because of access to antiretroviral therapies, an AIDS diagnosis is no longer the expected prognosis of HIV infection.

2. While not aiming to provide an exhaustive list, this article is indebted to previous discussions of TIM by Tim Dean (2009; 2015), Chris Ashford (2015), Susanna Paasonen (Morris and Paasonen 2014), Byron Lee (2014), Michael McNamara (2013), and Christien Garcia (2013).

3. For more on how, in the conventions of mainstream porn, the 'money shot' signals the conclusion of the scenes see, for instance, Murat Aydemir's study of how semen has been thought and represented in Western culture (Aydemir 2007, 95) and John Mercer's recent monograph on gay porn (Mercer 2017, 64-67).

4. See, for instance McCasker (2014), Clark-Flory (2014) and Terrell (2015).

5. 'Pythagorae Socratisque \& Platonis mos erat ubique divina mysteria figuris involucrisque obtegere, sapientiam suam contra Sophistarum iactantiam modeste dissimulare, iocari serio, \& studiosissime ludere' (Ficino 1962, 125). While Maude Vanhaelen's translation (Ficino 2012, 33) uses the phrase 'to jest in seriousness and to joke in the greatest earnest,' I decided to substitute 'to joke' by 'to play', following Michael Allen's translation (Allen 1986, 438), as 'to play' is also often used by gay men to mean 'to have sex.'

6. According to Anecdotes by the Rev. Percival Stockdale, one of the published sources where Johnson's sentence can be found, the correct wording should actually have been 'for he who makes a beast of himself gets rid of the pain of being a man' (Birkbeck Hill 1897, 333).

7. Available at http://store.treasureislandmedia.com/VIRAL-LOADS.html. Accessed 13 December 2017.

8. A pighole is a hollow butt plug. Because it is hollow, it allows access to the rectum through it.

\section{Acknowledgements}

Earlier versions of this argument were presented at Overflow: Performance Studies international Conference \#23 (Kampnagel, Hamburg, June 10, 2017), and Doing Sex: Men, 
Masculinities and Sexual Practices (Newcastle University, Newcastle, July 13, 2017). I am grateful to John Mercer for his invaluable feedback while writing and revising this article.

\section{References}

Aidsmap. "Survival outside the body." Accessed 27 December 2017. https://www.aidsmap.com/Survival-outside-the-body/page/1321278/

Allen, J. B. 1986. "The Second Ficino-Pico Controversy: Parmenidean Poetry, Eristic, and the One." In Marsilio Ficino e Il Ritorno di Platone: Studi e Documenti, edited by Gian Carlo Garfagnini, 417-455. Florence: Leo S. Olschki Editore.

Ashford, Chris. 2015. "Bareback sex, queer legal theory, and evolving socio-legal contexts." Sexualities 18 (1/2): 195-209.

Attwood, Feona. 2002. "Reading Porn: The Paradigm Shift in Pornography Research." Sexualities 5 (1): 91-105.

Attwood, Feona. 2018. Sex Media. Cambridge: Polity.

Aydemir, Murat. 2007. Images of Bliss: Ejaculation, Masculinity, Meaning. Minneapolis: University of Minnesota Press.

Birkbeck Hill, George, ed. 1897. Johnsonian Miscellanies. Vol. 2. Oxford: Clarendon Press.

Clark-Flory, Tracy. 2014. "When HIV is a turn-on.” Salon, April 15. Accessed 6 October 2017. http://www.salon.com/2014/15/when_hiv_is_a_turn_on/.

Cohen, Ed. 2009. A Body Worth Defending: Immunity, Biopolitics, and the Apotheosis of the Modern Body. Durham: Duke University Press.

De Angelis, Massimo. 2017. Omnia Sunt Communia: On the Commons and the Transformation to Postcapitalism. London: Zed Books.

De Lauretis, Teresa. 1987. Technologies of Gender: Essays on Theory, Film, and Fiction. Bloomington: Indiana University Press.

Dean, Tim. 2009. Unlimited Intimacy: Reflections on the Subculture of Barebacking. Chicago: University of Chicago Press.

Dean, Tim. 2015. "Mediated intimacies: Raw sex, Truvada, and the biopolitics of chemoprophylaxis." Sexualities 18 (1/2): 224-246.

Douglas, Mary. 2002. Purity and Danger: An Analysis of Concepts of Pollution and Taboo. London: Routledge.

Edelman, Lee. 2004. No Future: Queer Theory and the Death Drive. Durham: Duke University Press. 
Esposito, Roberto. 2010. Communitas: The Origin and Destiny of Community, Stanford: Stanford University Press.

Esposito, Roberto. 2011. Immunitas: The Protection and Negation of Life. Cambridge: Polity Press.

Ficino, Marsilio. 1962. Opera omnia. Torino: Bottega d'Erasmo.

Ficino, Marsilio. 2012. Commentaries on Plato. Vol. 2, Pt. I, edited and translated by Maude Vanhaelen. Cambridge, MA: Harvard University Press.

Foucault, Michel. 1978. The History of Sexuality, Volume I: An Introduction. New York: Pantheon Books.

Foucault, Michel. 1983. “Afterword: The Subject and Power.” In Hubert L. Dreyfus and Paul Rabinow, Michel Foucault: Beyond Structuralism and Hermeneutics, 208226. Chicago: University of Chicago Press.

Foucault, Michel. 1990. “The Return of Morality.” In Michel Foucault: Politics, Philosophy, Culture, edited by Lawrence D. Kritzman, 242-254. London: Routledge.

Foucault, Michel. 2003. The Birth of the Clinic: An Archaeology of Medical Perception. London: Routledge.

Foucault, Michel. 2005. The Hermeneutics of the Subject: Lectures at the Collège de France, 1981-82. New York: Palgrave Macmillan.

Garcia, Christien. 2013. "Limited intimacy: barebacking and the imaginary." Textual Practice 27 (6): 1031-1051.

Hedrick, Stephen M. 2004. "The Acquired Immune System: A Vantage from Beneath." Immunity 21: 607-615.

Kipnis, Laura. 1999. Bound and Gagged: Pornography and the Politics of Fantasy in America. Durham: Duke University Press.

Knox, Dilwyn. 1989. Ironia: Medieval and Renaissance Ideas on Irony. Leiden: E. J. Brill.

Lazzarini, Zita, Carol L. Galletly, Eric Mykhalovskiy, Dini Harsono, Elaine O’Keefe, Merril Singer, and Robert J. Levine. "Criminalization of HIV Transmission and Exposure: Research and Policy Agenda." American Journal of Public Health 103 (8): 1350-1353.

Lee, Byron. 2014. "It's a question of breeding: Visualizing queer masculinity in bareback pornography." Sexualities 17 (1/2): 100-120. 
Lee, Nathan. 2013. "Becoming-undetectable." e-flux 44. Accessed 13 December 2017. http://www.e-flux.com/journal/44/60170/becoming-undetectable/.

Lepage, John L. 2012. The Revival of Antique Philosophy in the Renaissance. New York: Palgrave Macmillan.

Maes, Hans. 2013. "Introduction." In Pornographic Art and the Aesthetics of Pornography, edited by Hans Maes, 1-24. Basingstoke: Palgrave Macmillan. McCasker, Toby. 2014. “A Porn Director Stirred Up Controversy by Making a Movie Centered Around HIV." Vice, May 12. Accessed 6 October 2017. http://www.vice.com/en_us/article/yvqbgm/director-paul-morris-believes-hivshould-be-part-of-gay-pon/.

McNamara, Michael. 2013. "Cumming to terms: Bareback Pornography, Homonormativity, and Queer Survival in the Time of HIV/AIDS." In The Moral Panics of Sexuality, edited by Breanne Fahs, Mary L. Dudy, and Sarah Stage, 226-244. Basingstoke: Palgrave Macmillan.

Mercer, John. 2017. Gay Pornography: Representations of Sexuality and Masculinity. London: I. B. Tauris.

Metchnikoff, Élie. 1905. Immunity in Infective Diseases. Cambridge: Cambridge University Press.

Morris, Paul. 2011. "No Limits: Necessary Dancer in Male Porn.” Treasure Island Media, November 15. Accessed 6 October 2017. https://blog.treasureislandmedia.com/2011/11/no-limits-necessary-danger-inmale-porn/.

Morris, Paul and Susanna Paasonen. 2014. "Risk and Utopia: A Dialogue on Pornography." GLQ 20 (3): 215-239.

Paasonen, Susanna. 2011. Carnal Resonance: Affect and Online Pornography. Cambridge, MA: The MIT Press.

Patton, Cindy. 1991. "Safe Sex and the Pornographic Vernacular." In How Do I Look? : Queer Film and Video, edited by Bad Object-Choices, 31-63. Seattle: Bay Press.

Pradeau, Thomas. 2012. The Limits of the Self: Immunology and Biological Identity. New York: Oxford University Press.

Preciado, Paul B. 2000. Manifeste contra-sexuel. Paris: Éditions Balland.

Preciado, Paul B. 2008. "Pharmaco-pornographic Politics: Towards a New Gender Ecology." Parallax 14 (1): 105-117. 
Preciado, Paul B. 2013. Testo Junkie: Sex, Drugs, and Biopolitics in the Pharmacopornographic Era. New York: Feminist Press at the City University of New York.

Race, Kane. 2009. Pleasure Consuming Medicine: The Queer Politics of Drugs. Durham: Duke University Press.

Rea, Michael C. 2001. "What is Pornography?” Nô̂s 35 (1): 118-145.

Ryan, Frank P. 2004. "Human endogenous retroviruses in health and disease: a symbiotic perspective." Journal of the Royal Society of Medicine 97: 560-565.

Tauber, Alfred. 2000. "Moving beyond the immune self?" Seminars in Immunology 12: $241-248$.

Tauber, Alfred. 2017. Immunity: The Evolution of an Idea. New York: Oxford University Press.

Terrell, Matthew. "Revolutionary Thinking To Inspire The Gay Community." Huffpost, December 21. Accessed 28 December 2017. https://www.huffingtonpost.com/matthew-terrell/revolutionary-thinkingto_b_8851614.html

Tomso, Gregory. 2008. "Viral Sex and the Politics of Life." South Atlantic Quarterly 107 (2): 265-285.

Turner, Victor. 1995. The Ritual Process: Structure and Anti-Structure. New Brunswick: AldineTransation.

Williams, Linda. 2014. "Pornography, Porno, Porn: Thoughts on a Weedy Field." In Porn Archives, edited by Tim Dean, Steven Ruszczychy, and David Squires, 2943. Durham: Duke University Press. 